\title{
COMPARISON OF EFFECTS OF LOW AND HIGH TICK INFESTATIONS ON ACQUIRED CATTLE TICK RESISTANCE: HYALOMMA MARGINATUM MARGINATUM
}

\author{
SAHIBI H.*, RHALEM A.* \& TIKKI N.*
}

\section{Summary :}

Three Holstein calves were infested with low numbers of ticks, two or three pairs of adults Hyalomma marginatum marginatum in cloth bag daily for 21 days. Infestation was carried out during tick proliferation periods. Two months later, cattle leads were challenged with 100 pairs of ticks. Another group of three Holstein calves were infested five times with 100 pairs of adult ticks of the same species. The five infestations were performed two weeks from the previous infestation. Three tick characteristics were recorded for each experiment: survival to detachment, females weight at detachment and egg mass weight. Light continuous infestations did not cause a significant change in this parameter, but every parameter declined gradually in the heavy infestations. Female and egg mass weight reached a significant difference from the first infestation by the fourth infestation. The circulating antibodies anti-salivary glands of Hyalomma m. marginatum showed that light infestation may induce like immuno-suppression. However, there is an inverse relationship between these antibodies and manifestation of resistance when calves were heavily infested. This is discussed in relation to a fraction of produced antibodies against protective antigens, and participation of another effector mechanism

KEY WORDS : ticks, Hyalomma marginatum marginatum, low and continuous infestations, repeatedly heavy infestations, resistance, humoral response.
Résumé : COMPARAISON DES EFFETS D'INFESTATIONS LÉGÈRES ET MASSIVES, PAR DES TIQUES HYALOMMA MARGINATUM MARGINATUM, SUR L'ACQUISITION DE LA RÉSISTANCE PAR LES BOVINS

Trois bovins de race Holstein ont été infestés par deux à trois paires de tiques adultes de l'espèce Hyalomma m. marginatum, chaque jour pendant 21 jours. Les infestations ont été réalisés pendant la période d'activité des tiques. Une infestation d'épreuve avec 100 paires de tiques a été faite deux mois après la dernière infestation. Un second groupe de trois bovins de la même race a fait l'objet de cinq infestations massives 1100 paires de tiques par infestation) à intervalles de 15 jours et cela après gorgement de la dernière tique de l'infestation précédente. Au cours de cette étude trois paramètres ont été suivis : la survie au détachement, le poids des tiques femelles et enfin la masse d'œufs. Les infestations continues et modérées n'ont pas provoqué de changement significatif des paramètres suivis. Par contre, les infestations massives ont causé une baisse progressive et significative de ces paramètres. Le poids des tiques femelles et la masse d'œufs marquent une baisse significative à partir de la $4 \dot{e}$ 5 infestation. Les anticorps circulant dirigés contre les glandes salivaires de la tique Hyalomma m. marginatum ont montré que les infestations modérées induisent probablement une immunosuppression. Toutefois, une relation inverse a été constatée entre les anticorps circulants et l'acquisition de la résistance chez les animaux massivement infestés, ceci est discuté en relation avec la fraction des anticorps formée contre les antigènes protecteurs et avec la participation d'un autre mécanisme effecteur.

MOTS CLÉS : tiques, Hyalomma marginatum marginatum, infestations légères et continues, infestations lourdes et répétées, résistance, réponse humorale.

\section{INTRODUCTION}

T icks and diseases they transmit to animals are of worldwide economic importance. The cost of acaricide applications, the issue of environmental pollution and the development of resistance to acaricides (Beugnet et al., 1994) have made a research priority to establish cheap, effective and environmentally acceptable tick control methods. There is a large body of evidence that shows that animals develop

\footnotetext{
* Département de Parasitologie et Maladies Parasitaires, Institut Agronomique et Vétérinaire Hassan II, B.P. 6202, Rabat-Instituts, Maroc.

Correspondence : Hamid Sahibi.

Fax : 21276804 24/7 778135.
}

resistance against ticks under laboratory conditions (Wikel, 1988; Fivaz, 1990; Rechav et al., 1991; Wikel et al., 1994). Repeated infestations resulted in significant reduction in the number of ticks that successfully completed their blood meal, and in the mean weight of ticks feeding on resistant hosts. All studies demonstrated that guinea pigs and rabbits subjected to repeated infestations with ticks of different species acquired resistance (Fivaz, 1990; Fielden et al., 1992; Losel et al., 1993; Rechav et al., 1994; Rechav \& Fielden, 1995). Small ruminants also can acquire resistance against ticks. Indeed, Barriga et al. (1991) found that repeated infestations with 100 pairs of Amblyomma americanum (L.) induce strong but incomplete protection in sheep by the fourth or fifth infestation. Adamson et al. (1991) demonstrated that goats acquired 
resistance to larvae of Amblyomma bebraeum (Koch) after to three infestations. It has long been recognized that various cattle breeds differed in their response to tick infestations (Rechav \& Kostrzewski, 1991; Fivaz et al., 1991; Garris \& Hair, 1992, Ali \& De Castro; 1993, Moran et al., 1996). At present, acquired resistance of cattle to natural tick infestation is well-documented (Amoo \& Dipeolu, 1992; Dipeolu et al., 1992; Barriga et al., 1993). However, Sahibi et al. (1997a) recently demonstrated failure due to age and breed to acquire resistance under field conditions. In this paper, low intensity infestation under natural conditions in the field is compared to the effect of high intensity, repeated infestations with adult ticks Hyalomma m. marginatum, under controlled laboratory conditions.

\section{MATERIALS AND METHODS}

TiCKS

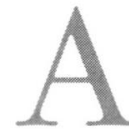

colony of H. m. marginatum Koch, 1844 ticks was maintained at Institut Agronomique Vétérinaire Hassan II, Rabat-Morocco, at $85 \pm 5 \%$ relative humidity, and $28^{\circ} \pm 1{ }^{\circ} \mathrm{C}$. Larvae and nymphs were confined to ears of rabbits using cloth-bags, and adults were fed on sheep using the same method.

In all experiments, four to five week-old adults ticks were used to infest cattle. To monitor the effect of host resistance on egg-laying and egg-hatching, the engorged females were kept individually in glass tubes and maintained at a constant temperature of $28{ }^{\circ} \mathrm{C}$ and $85 \%$ relative humidity for 30 days.

\section{Hosts}

Nine Holstein calves (males), height to twelve months old weighing $70-80 \mathrm{~kg}$ were divided into three groups of three animals each. The animals were carefully examined for evidence of tick infestation as part of a thorough physical exam. During the experiments, they were kept on a small plot with bare dry ground which prevented spontaneous new tick infestation. The calves were fed artificially with cattle pellets and fresh alfalfa, and provided fresh water ad libitum.

\section{- Experiment 1}

Effect of low level repeated infestations under laboratory conditions.

Under field conditions, cattle are infested with an average of two or three tick pairs per day. Our experiment coincided with the season of high risk infestation (from June to August). Each calf of the first group received two or three pairs of ticks every day for a 21 day period. Female ticks that had detached were collected daily until they all completed their feeding and detached. Two months after the end of the last infestation, the cattle was challenged with 100 pairs of H. m. marginatum adult ticks. Survival to detachment, engorgement weight and weight of the egg mass were recorded to assess resistance.

\section{- Experiment 2}

Effect of high intensity infestations on tick characteristics.

Calves of the second group were subjected to five consecutive infestations with 100 pairs (100 males and 100 females) of $H$. m. marginatum each. Ticks were deposited in a cloth sack and confined to both ears of the calves. Sacks were examined daily and the number of engorged ticks was recorded until all ticks which engorged had detached. Each female was weighed and incubated in individual containers $(8 / 2.5 \mathrm{~cm})$ until the end of the oviposition period, or discarded after 30 days if it failed to oviposit. The weight of the egg mass was also recorded. The five infestations were done at two week intervals, after the last tick from the previous infestation had detached.

\section{SEROLOGY}

Calves of the first experiment were bled before infestation and every seven days for 17 weeks thereafter. Likewise, cattle of the second experiment were bled at each of the five infestations. A third group of three calves was used as a uninfested group, and was bled during all stages of the experiments. Antibody levels against salivary gland antigens were determined in sera from animals in all experiments using the ELISA test.

\section{ELISA}

The procedure described by Engvall \& Perlman (1971) was followed. Ninety-sixwell flat-bottom microplates [Probind (Becton Dickson)] were coated with $5 \mu \mathrm{g} /$ well of protein antigens derived from the pooled salivary glands of ticks that had fed for five days. Salivary gland extracts were diluted in carbonate bicarbonate coating buffer, $\mathrm{pH}=9.6$, and incubated for two hours at $37^{\circ} \mathrm{C}$ and over night at $4{ }^{\circ} \mathrm{C}$. After three washings with phosphate buffered saline (PBS) containing $0.05 \%$ Tween20 (PBS-T $0.05 \%$ ), the microplates were incubated for one hour at $37{ }^{\circ} \mathrm{C}$ with PBS-T $2 \%$ in order to inhibit non specific binding. After three more PBS-T $0.05 \%$ rinses, $100 \mu \mathrm{l}$ of cattle sera diluted to $1 / 100$ in PBS-T $0.05 \%$ were added (all samples were tested in triplicate) and plates were incubated for one hour at $37^{\circ} \mathrm{C}$. After one washing, $100 \mu \mathrm{l}$ of peroxidase labelled rabbit anti-bovine IgG (Cappel Lab. Westchester Pennsylvania), diluted 1/1,000 in PBS were added to each well. 
The plates were incubated for an additional one hour at $37^{\circ} \mathrm{C}$, and after another three washings with PBST $0.05 \%, 100 \mu \mathrm{l}$ of substrate solution (Orthophenylene diamine $(10 \mathrm{mg})+1 \mathrm{ml}$ methanol $+100 \mu \mathrm{H}_{2} \mathrm{O}_{2}$ and $99 \mathrm{ml}$ water) were added to the wells. The assays were read at an optical wave length of $492 \mathrm{~nm}$ using an automatic ELISA plate reader.

\section{STATISTICAL ANALYSIS}

Data were analyzed using the general linear model. Since the methodology in this experiment falls within the principle of repeated measures design (Gill, 1990), the repeated measured (multivariate) analysis of variance was adopted using the Statistical Analysis Systems (SAS) program. Since the same group of animals was analyzed over a time period, our main interest was to ascertain whether the protection afforded by acquired resistance increases with successive infestations. In all tests, significance was assessed at a level of $\mathrm{P}<0.05$.

\section{RESULTS}

\section{EXPERIMENT 1}

he effect of light infestations with H.m. marginatum adult ticks is shown in Table I-A. Low level continuous intensity infestations cause a decline but not significant change in the parameters measured for assessing tick viability and feeding success (survival to detachment, weight of females at detachment, weight of egg mass). Ticks in the challenged groups (100 pairs), also did not show any significant differences $(P>0.05)$ in these characteristics (Table I-B).
With regard to antibody production, there was an increase in the average level from $(0.20 \pm 0.02 \mathrm{SD})$ to $(0.87 \mathrm{OD} \pm 0.07 \mathrm{SD})$ by the third week after the first infestations, followed by a sharp decline and fluctuating readings ( 0.37 to $0.25 \mathrm{OD}$ ) for almost nine weeks thereafter (Fig. 1). Three weeks after the challenge, a new antibody peak appeared (0.57 OD \pm 0.05 ) (Fig. 1). The difference between peaks was statistically significant $(\mathrm{P}<0.05)$.

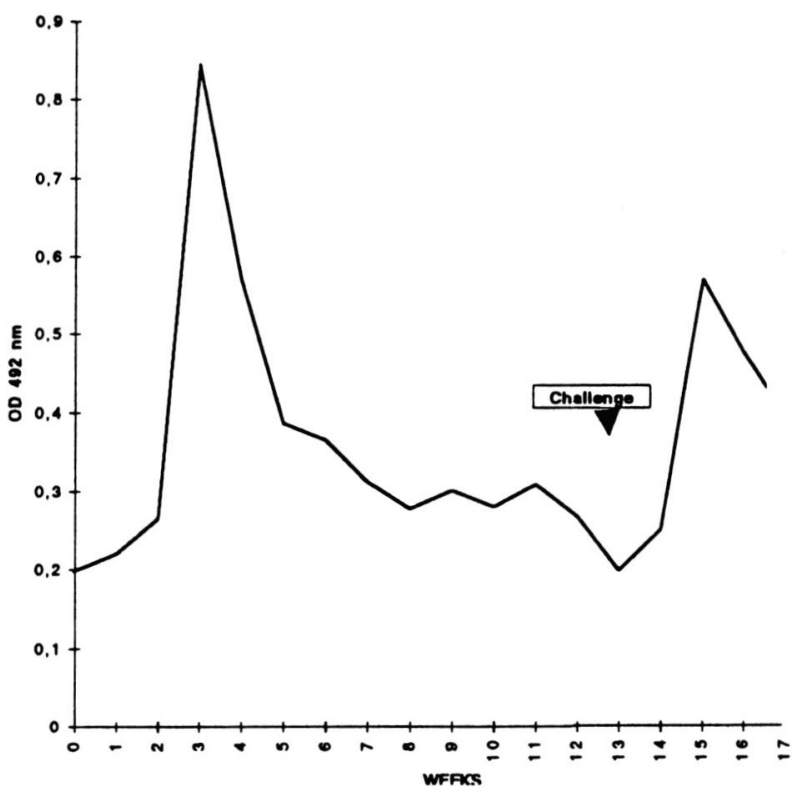

Fig. 1. - Antibody level to salivary extracts as determined by ELISA in sera of three calves infested with low rates if Hyalomma m. marginatum. The arrow corresponds to the challenge with 100 pairs of Hyalomma $m$. marginatum ticks.

A. Result of 21 light infestations with Hyalomma marginatum marginatum in cattle

\begin{tabular}{lccccc}
\hline \multicolumn{1}{c}{ Tick Characteristics } & Control & Calf 1 & Calf 2 & Calf 3 & Average \pm SD \\
\hline Survival to detachment mg & 93 & 92 & 86 & 95 & $91 \pm 3.5$ \\
Weight at detachment mg & 779 & 796 & 618 & 578 & $664 \pm 95$ \\
Weight of egg mass (mg) & 396 & 392 & 272 & 217 & $294 \pm 73$ \\
\hline
\end{tabular}

Control: mean data of three calves infested one time by 100 pairs of Hyalommma m. marginatum adult ticks.

B. Comparison of the results of 21 light infestations and a heavy challenge on Hyalomma marginatum marginatum of cattle

\begin{tabular}{lcc}
\hline \multicolumn{1}{c}{ Tick Characteristics } & Average 21 infestations & $\begin{array}{c}\text { Average } 21 \text { infestations } \\
\pm \text { challenge }\end{array}$ \\
\hline Survival to detachment (\%) & $91 \pm 3.7$ & $84.5 \pm 5.7$ \\
Weight at detachment (mg) & $664 \pm 95$ & $645 \pm 88$ \\
Weight of egg mass (mg) & $294 \pm 73$ & $290 \pm 37$ \\
\hline
\end{tabular}

Table I. - Lack of resistance to low intensity repeated infestations with adult Hyalomma marginatum marginatum (two-three tick pairs added each day for 21 days). 


\section{EXPERIMENT 2}

During high intensity repeated infestations, the number of ticks which survived to detachment and ovipositioning declined gradually and reached a significant difference from the first infestation only by the fifth infestation. Detachment weights showed a similar trend. The average weight at detachment was slightly higher by the second compared to the first infestation, but all the ticks were significantly smaller $(P<0.05)$ at the fourth infestation.

Most of the non-viable ticks (affected ticks) were either dark red-brown with smooth distended cuticles, or light green-yellow and turned dark with time. The average weight per egg mass dropped markedly by the third infestation to $66 \%$ reduction after the fourth infestation (Table II). A comparison revealed significant changes in all the parameters measured during the first, fourth and fifth infestations (Table II).

The ELISA test showed that the first infestation caused an important antibody production reaching a peak at Day 15 post infestation (from $0.10 \pm 0.02$ to $1.07 \pm 0.04$ ) and declining thereafter (Fig. 2). During the second infestation, the rate of antibodies increased again and dropped 15 days thereafter. Each of the following three infestations, however, resulted in a progressive decline in antibody levels. Antibody levels dropped within a month from the last infestation.

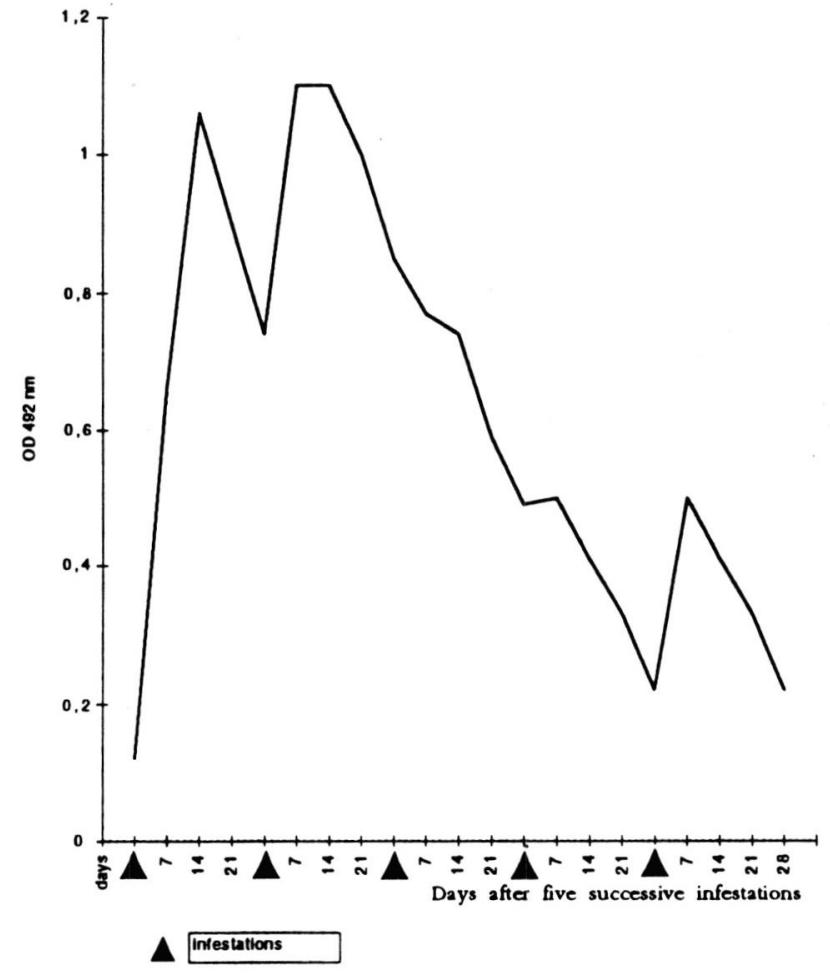

Fig. 2. - Antibodies against an extract of five-day-fed salivary gland of Hyalomma m. marginatum detected by enzyme-linked immunosorbent assay (ELISA) in the sera of three calves taken before infestations and during the first weeks of each infestation by Hyalomma $m$. marginatum.

\begin{tabular}{lccccc}
\hline & \multicolumn{4}{c}{ Infestations } \\
\cline { 2 - 6 } \multicolumn{1}{c}{ Tick characteristics } & 1st & 2nd & 3rd & 4th & 5 th \\
\hline \% of females engorged & $68 \pm 14$ & $74 \pm 8$ & $80 \pm 10$ & $53 \pm 8$ & $41 \pm 4^{*}$ \\
Female weight (mg) & $825 \pm 31$ & $861 \pm 17$ & $607 \pm 87$ & $267 \pm 23^{*}$ & $296 \pm 23^{*}$ \\
Egg mass weight (mg) & $478 \pm 16$ & $457 \pm 47$ & $349 \pm 52$ & $164 \pm 38^{*}$ & $129 \pm$ \\
\hline
\end{tabular}

(The value represents an average number; results followed by a symbol were significant.)

Table II. - Tick characteristics during five infestations of three calves with Hyalomma marginatum marginatum.

\section{DISCUSSION}

T he current study investigated the effect of light and heavy repeated infestations of cattle on ticks. Simulation of field conditions in the laboratory using light and continuous infestations with Hyalomma marginatum marginatum showed that the following tick parameters (\% of ticks engorged, engorged female weight and egg mass weight),were not influenced (Table I). Light intensity infestation did not confer resistance under laboratory conditions. These results appear to closely reflect what occurs under field conditions. Possibly hosts become tolerant to the parasite because of continuous stimulation with low levels of antigens. Ticks may be able to evade the host's immune system by inoculating immunogenic materials which react with antibodies to form immune complexes that could deflect the immune response of the host to ticks. The tick may also inoculate immunesuppressive materials to abolish the immune response (Ribeiro et al., 1990; 1992; 1995).

Heavy repeated infestations induced in cattle partial resistance against Hyalomma marginatum marginatum adult ticks after three infestations. This resistance was manifested by an inhibition of tick feeding and fertility (Table II). The percentage of engorged females was significantly affected at the forth and fifth infestations compared to the first infestation, dropping to $55 \%$. Female weight was also affected from the third to the fifth infestation (by $68 \%$ ). Likewise, egg mass weight dropped from the third infestation to reach $66 \%$ by the fifth infestation. There is enough evidence to sug- 
gest that frequent reinfestations of cattle can confer a resistance, but the mechanism responsible for maintaining this resistance remain to be investigate. Similar results were found with other species of ticks (Dipeolu et al., 1992). The tick Boophilus microplus (Canestrini) responded basically in the same way (Barriga et al., 1993; 1995). Opdebeeck et al. (1988) found that Hereford immunized with extracts of tick guts gave a protection of $36 \%$ for seven months.

Circulating antibodies against salivary gland antigens of Hyalomma marginatum marginatum were detected by ELISA. During a low intensity infestation the antibody titer increased after three weeks, but declined rapidly to remain low. Three weeks after the challenge, the antibody titer increased slightly, and later dropped again. As results we noticed that low intensity infestations induced immunosuppression rather than immunoprotection. However, our results showed that cattle can acquire tick resistance after heavy repeated infestations. This resistance could be attributed to the immune response of the host. Circulating antibodies were detected during the five infestations. It seems that the first infestation suppress the occurrence of secondary response induced by the second infestation. However, it did not suppress all antibody production as it occurs in low intensity infestations. Each one of the last three infestations resulted in lower antibody levels and antibody productions declined during the month following the infestations. Around the fifth infestation, the average level was only $30 \%$ of the level found of the first infestation. The same results were found in sheep infested with Amblyomma americanum (L.) (Barriga et al., 1991). Schorderet \& Brossard (1993) established that heavily infested rabbits produced a higher titer of antibodies and the lympho-proliferative response was higher compared to lightly infested rabbits.

An inverse relationship between antibody response and manifestation of resistance was observed. Therefore the likelihood of a phenomenon of competition between irrelevant and protective antigens is suspected. Antibody titers were low when manifestations of resistance became conspicuous at infestation. This suggests that antibodies were not the main effectors of anti-tick protective immunity, or that protective antibodies were only a small fraction of the antibody population formed against tick antigens. Some studies demonstrated that complement and cellular responses were effector mechanisms (Wikel et al., 1978; Wikel, 1979; George et al., 1985; Wikel, 1996). In fact, several investigation related to immunization with tick extracts have highlighted the existence of a resistance to the host with the development of humoral and cellular response (Banerjee \& Momin, 1990; Tembo \& Rechav, 1992; Sahibi et al., 1997b; Sahibi et al., 1997c).
This study showed no relationship between natural resistance and the ability to acquire resistance. The field conditions are propitious for immune-suppression, which probably explains the abundance and wide distribution of ticks. The incomplete immune resistance established after repeated heavy infestations suggests that ticks were able to evade host immunity with their salivary glands secretion (Inokuma et al.,1993; Wikel et al., 1994). This intense antigenic stimulation favors the suppression of specific immune response to ticks. However, an anti-tick vaccine can be developed, if protective antigens were identified and quantified to induce resistance and to record the time length of such resistance.

\section{REFERENCES}

Adamson D., Fivaz B.H., \& Petney T.N. Acquisition of resistance to the bont tick Amblyomma bebraeum (Acarina: Ixodidae) by goats. Veterinary Parasitology, 1991, 38, 317-326.

Ali M. \& DE CASTro J.J. Host resistance to ticks (Acari: Ixodidae) in different breeds of cattle at Bako, Ethiopia. Tropical of animals bealth production, 1993, 25, 215-222.

Amoo A.O. \& Dipeolu O.O. Host resistance to Ixodidae ticks: response of tick naive calves to repeated infestation with larvae of Boophilus decoloratus (Koch, 1844) and Boophilus geigyi (Aeschliman and Morel,1965). Insect science and it's application, 1992, 13, 813-818.

BANERJEe D.P. \& Momin R. Immunization of cattle and rabbits against the Ixodidae tick Hyalomma anatolicum anatolicum. Bulletin de la société française de Parasitologie, 1990, 68, 636.

Barriga O.O., ANDUJar F. \& ANDRZEJESKi W.J. Manifestation of immunity in sheep repeatedly infested with Amblyomma americanum ticks. Journal of Parasitology, 1991, 77, 703-709.

Barriga O.O., Sergio S., Da silvia, \& Azevedo J.S.C. Inhibition and recovery of tick functions in cattle repeatedly infested with Boophilus microplus. Journal of Parasitology, 1993, 79 (5), 710-715.

Barriga O.O., Da Saliva S.S. \& Azevedo J.S. Relationships and influences between Boophilus microplus characteristics in tick-naive or repeatedly infested cattle. Veterinary Parasitology, 1995, 56 (1-3), 225-238.

Beugnet F., Costa R. \& Chardonnet L. Adaptations des méthodes de lutte contre les tiques à l'extension du phénomène chimiorésistance : exemple de Boophilus microplus en Nouvelle-Calédonie. Revue de médecine Vétérinaire, 1994, 145 (12), 931-940.

Dipeolu O.O., Mongi A.O., Essuman S., Amoo A.O. \& NDUNGU J.N. Studies on naturally acquired immunity to African ticks. II/ Observations on cattle exposed to Rhipicephalus appendiculatus under varying periods of repeated infestations. Veterinary Parasitology, 1992, 41, 293-320. 
Engvall E. \& Perlman P. Enzyme linked immunosorbant assay (ELISA), quantitative assay of immunoglobulin G. Immunochemistry, 1971, 8, 871-874.

Fielden L.J., Rechav Y. \& Bryson N.R. Acquired immunity to larvae of Amblyomma marmoreum and $A$. bebraeum by tortoises, guinea-pigs and guinea-fowl. Medical and Veterinary Entomology, 1992, 6, 251-254.

Fivaz B.H. Immunological responses of the rabbit host to infestation by the brown ear-tick Rhipicephalus appendiculatus (Acarina: Ixodidae). Experimental and Applied Acarology, 1990, 9, 219-238.

Fivaz B.H., Nurton J.P. \& Petney T.N. Resistance of restrained Bos taurus dairy bull calves to the bout tick Amblyomma hebraeum (Acarina: Ixodidae). Veterinary Parasitology, 1991, 38, 299-315.

GARRIS G.I. \& HAIR J.A. Feeding performance and survival of Amblyomma americanum (Acaris: Ixodidae) on resistant Bos taurus and Bos indicus cross bred heifers. Journal of Agricultural Entomology, 1992, 9, 321-337.

George J.E., Osbum R.L. \& Wikel S.K. Acquisition and expression of resistance by Bos indicus and Bos indicus x Bos taurus calves to Amblyomma americanum infestation. Journal of Parasitology, 1985, 71, 174-182.

GiLL J.L. Uses and abuses of statistical methods in research in Parasitology. Veterinary Parasitology, 1990, 36, 189-209.

Inokuma H., Kerlin R.L., Kemp D.H. \& Willadsen P. Effects of cattle tick (Boophilus microplus) infestation on the bovine immune system. Veterinary Parasitology, 1993, 47, 107118.

Losel P.M., Guerin P.M. \& Diehl P.A. Contrasting effects of sera from rabbits and cattle infested with ticks on the in vitro feeding performance of the tick Rhipicephalus appendiculatus. Veterinary Parasitology, 1993, 47, 355-60.

Moran M.C. Niagrura G. \& Pegram R.G. An assessment of host resistance to ticks on cross-bred cattle in Burundi. Medical and Veterinary Entomology, 1996, 10, 12-18.

Opdebeeck J.P., Wong J.Y.M., Jackson L.A. \& Dobson C. Vaccines to protect Herford cattle against the cattle tick, Boophilus microplus. Immunology, 1988, 63, 363-367.

Rechav., Clarke F.C., Els D.A. \& Dauth J. Development of resistance in laboratory animals to adults of the tick $R h i$ picephalus evertsi evertsi. Medical of Veterinary Entomology, 1991, 5, 29-34.

ReCHAV Y. \& KostrzewsKi M.W. Relative resistance of six cattle breeds to the tick Boophilus decoloratus in south Africa. Onderstepoort Journal of Veterinary Resherch, 1991, 58, 181-186.

Rechav, Magano S.R. \& Fielden L.J. The effects of tick numbers and intervals between infestations on the resistance acquired by guinea-pigs to adults of Rhipicephalus evertsi evertsi (Acari: Ixodidae). Experimental \& Applied Acarology, 1994, 18, 735-745.

Rechav Y. \& Fielden L.J. The effect of host resistance on the metabolic rate of engorged females of Rhipicephalus everts $i$ evertsi. Medical and veterinary entomology Oxford. Black well scientific limited, 1995, 9, 289-292.
Ribeiro J.M.C., Weis J.J. \& Telford III S.R. Saliva of the tick Ixodes dammini inhibits neutrophil function. Experimental Parasitology, 1990, 70, 382-388.

Ribeiro J.M.C., Evass P.M., Mac Swain J.L. \& Sauer J. Amblyomma americanum: Characterization of salivary prostaglandins $\mathrm{E}_{2}$ and $\mathrm{F}_{2 \mathrm{a}}$ by RP-HPLC/Bioassay and gaz chromatography-mass spectrometry. Experimental Parasitology, 1992, 74, 112-116.

Ribeiro J.M.C. How ticks make a living. Parasitology today, 1995, 11 (3), 91-93.

Sahibi H., Rhalem A., Tikki N., Ben Kouka F. \& Barriga O.O. Hyalomma ticks: Bovin resistance under field conditions as related to host age and breed. Parasite, 1997a, 4, 159165 .

Sahibi H., Rhalem A. \& Barriga O.O. Field and artificially induced resistance of cattle to Hyalomma marginatum Koch (Ixodidae). Acarology IX : proceedings, section, 8, Mites E Allergies, $1997 b, 8,519-521$.

Sahibi H., Rhalem A. \& Barriga O.O. Comparative immunization power of infections, salivary extracts, and intestinal extracts of Hylomma marginatum marginatum in cattle. Veterinary Parasitology, 1997c, 68, 359-366.

SCHOderet S. \& Brossard M. Changes in immunity to Ixodes ricinus by rabbits infested at different levels. Medical and Veterinary Entomology, 1993, 7, 186-192.

TEMBO S.D. \& RECHAV Y. Immunization of rabbits against nymph of Amblyomma hebraeum and marmoreum (Acari: Ixodidae). Journal of Medical Entomology, 1992, 29, 75776.

Wikel S.K., Graham J.E. \& Allen J.R. Acquired resistance to ticks. IV/ Skin reactivity and in vitro lymphocyte responsiveness to salivary gland antigens. Immunology, 1978, 32, 257-263.

WIKEL S.K. Acquired resistance to ticks expression of resistance by C4-deficient Guinea pigs. American Journal of Tropical Medicine and Hygiene, 1979, 28, 586-590.

WIKEL S.K. Immunological control of hematophagous antropod vectors: Utilization of novel antigens. Veterinary Parasitology, 1988, 29, 235-264.

Wikel S.K., Ramachandra R.N. \& Bergman D.K. Tick-induced modulation of the host immune response. International Journal for Parasitology, 1994, 24, 159-166.

Wikel S.K. Host immunity to ticks. Annual Review of Entomology, 1996, 41, 1-2.
Reçu le 23 juin 1997

Accepté le 7 novembre 1997 